\section{Corporate responsibility reporting according to Alobal Reporting Initiative: an international comparison}

Ionela-Corina CHERSAN, „Alexandru loan Cuza” University of laşi, Romania, e-mail:macov@uaic.ro

\section{Alsstract}

The Global Reporting Initiative (GRI) is an organization that has managed to impose its reporting practices on corporate responsibility among large transnational companies. The model proposed by GRI is based on the supposed convergence between the economic, social and environmental dimensions of sustainable development. This convergence can be presumed at macroeconomic level, but at the level of enterprises, the three dimensions are often divergent. By analyzing the structure of reports included in the GRI database, our article aims to identify the factors that impact on company's behavior in the corporate responsibility reporting process. In addition, our research invites to answer the following question: is it not possible that these reports attempt to exaggerate company environmental and social performance, rather than to cause a change in their conduct?

Keywords: GRI, OECD, corporate reporting, corporate social responsibility, empirical study

JEL Classification: M14, M48

To cite this article:

Chersan, I.C. (2016), Corporate responsibility reporting according to Global Reporting Initiative: an international comparison, Audit Financiar, vol. XIV, no. 4(136)/2016, pp. 424-435, DOI: 10.20869/ AUDITF/2016/136/424.

Permanent link to this document:

http://dx.doi.org/10.20869/AUDITF/2016/136/424. 


\section{Introduction}

Over the past 35 years, there has been a significant increase in the number of standards concerning corporate social responsibility, coupled with a similar increase in their popularity. Thus, Ligteringen and Zadek (2005) notice that there are approximately 300 standards relative to corporate responsibility at global level and that all these standards and codes can be divided into three categories:

1. Normative frameworks which instruct companies what to do;

2. Guides which instruct companies how to evaluate and communicate information about their actions; and

3. Management systems which help companies integrate their activities.

Amidst this multitude of standards, Global Report Initiative (GRI) offers a guide through which environmental problems should be better connected to the other aspects that are fundamental in promoting the development of a sustainable society (Marimo, AlonzoAlmeida and Rodriguez, 2012). A significant number of researchers and institutions consider that $\mathrm{GRI}$ is the most frequenytly used standard at world level in corporate non-financial reporting (Skouloudis, Evangelinos and Kourmousis, 2009; Prado-Lorenzo, Gallego-Alvarez and Garcia-Sanchez, 2009).

Over the past years, it has been noticed that increasingly more companies have got involved voluntarily in the process of issuing and implementing corporate social responsibility standards, and especially environmental standards. Certain authors (Chersan, 2015) show that, as a result of their rising responsibility towards the society, companies have started publishing information on the impact of their activity on the environment, information on their own employees and aspects that are connected to corporate social responsibility, in separate reports that accompany financial statements made available to shareholders.

The so-called voluntary compliance implies going beyond legal obligations. Schwindenhammer (2013) studied company voluntary norm adoption and identified two types of behaviors:

- companies that contribute to the process of establishing and developing norms and consequently, they are considered normentrepreneurs, and
- companies that accept and implement certain norms and are considered norm-consumers. Normconsumers can be grouped in two categories: those that accept norms and those that implement them.

Norm acceptance occurs after the institutionalisation of norms and it implies the fact that companies publicly admit that the norms have been adopted. Unlike norm acceptance, norm implementation always supposes an individual effort of the company that has to adjust its practices, especially in the field of corporate reporting.

Taking into account the degree of norm acceptance and implementation, Schwindenhammer (2013) identified three categories of entities:

- those that accept and implement international norms comprehensively (all-embracing norm-consumer);

- those that admit that their activity occurs under the incidence of these norms, but implement them incompletely and inconsequently (incomplete normconsumer), and

- those that reject the acceptance and implementation of the norms (non-consumer).

The current company behaviour relative to the acceptance of the GRI corporate reporting model can be explained as follows, in a nutshell:

"If you want to be a 'global player' that is now socially accepted, you must at least subscribe to a few international norms concering human rights and environmental protection, and issue reports that would highlight the efforts to implement these norms via changes in management and production rules" (Risse, 2007, p. 135).

We are going to make two types of analysis in the article:

1. An analysis of the origin of the companies which publish sustainability reports according to $\mathrm{GRI}$, from the geographical point of view and from the belonging to the OECD;

2. An analysis of the entities which include reports in the GRI database from the point of view of the activity sector, of the size of the companies and of the GRI guidelin applied.

This paper is structured as it follows: in the next secton we presented a revision of the literature regarding the GRI reporting. A presentation of the research methodology and of the result of the study follow. The 
paper ends with the discussions and conclusions of the research.

\section{Literature review on reporting according to GRI}

GRI has been launched in 1999 and since then a generally accepted framework on sustainability reports content, format and style has been developed (Brown, de Jong şi Lessidrenska, 2009), which has extended companies' responsibility beyond their traditional role to publish financial information. After the third generation of GRI guides - G3 was published in 2006, 2013 saw the emergence of a fourth generation of GRI guides - G4, as a result of an extended and structured process of public consultation. Let us mention here that GRI does not monitor compliance with norms, nor does it sanction incompliance; it only requires companies to declare their level of applying the general GRI framework, thus differentiating between categories of firms that report according to these standards. Actually, the GRI guide suggests the ways in which a company can show what it does and, although it does not require organisational changes or external company performance appraisal, GRI carries out evaluations that analyze a company's adjustment to the issued guides. In order to increase the credibility of the issued reports, the latter are often checked by auditing firms such as Deloitte, PriceWaterhouseCoopers, KPMG or Ernst \& Young. Over the last years, there has been a singnificant increase in the number of companies that apply $\mathrm{G} 3$ in their reporting process; this is the case especially with transnational companies from OECD

(Schwindenhammer, 2013). Also, with the emergence of G4, we have identified an increase in reporting according to this latest guide, paralleled by the decrease in the number of companies that report according to G3. Actually, the very purpose of developing such guides is to offer better reporting solutions; therefore, the observed phenomenon is logical and it also occurred in the transit stage from $\mathrm{G} 3$ to $\mathrm{G} 3.1$.

In the same line of thought, Marimon, Alonzo-Almeida and Rodriguez (2012) argue that the objective of the GRI guide is to create reports that would complement, rather than replace, other company reports. GRI reports contain information related to a company's economic, environmnetal and social issues. This approach, known as Triple Bottom Line (Elkington, 1994), also incorporates the so-called " 3 p's" (people, planet and profit) and it offers a general framework that allows the evaluation and reporting of an entity's results based on economic, social and environmental parameters.

Writing about the reporting model proposed by GRI, Prado-Lorenzo, Gallego-Alvarez and Garcia-Sanchez (2009) state that it is a harmonized, standardized, easy to understand and objective report for companies worldwide. Also, Clarkson, Overell and Chapple (2011) state that recent studies indicate a significant relation between information published voluntarily (mentioned in the GRI guide) and environmental performance.

In 2011, the European Commission, upon revising the previous definition of corporate social responsibility, stated that it represents "the responsibility of enterprises for their impact on society" (European Commission, 2011, p.6). Thus, the new definition approaches companies in their discovered capacity as partners that can establish rules, namely as entities that have the technical expertise or important financial resources available that can be used to solve environmental issues.

Ligteringen and Zadek (2005) recommend companies the following actions that would lead to convergence around a set of standards, instruments and guides:

- adopting standards which will constitute the most probable general global framework concerning sustainability;

- promoting these standards, instruments and guides, investing in their development and adoption by others;

- supporting actions that allow companies to integrate the use of key standards, instruments and guides, so as to increase efficiency and create value;

- participating actively in standard development.

At the same time, one can state that the adoption of corporate social resposibility practices takes different paths in different countries of the world due to cultural, legal, political, economic and social differences. Thus, Konrad et al. (2006) argue that firms in developed countries wish to boost their reputation; hence, they highlight gender and minority issues from their internal activity, and they point out social activities as external activities. Developing countries wish to achieve visibility for international investors and, consequently, they focus on compliance with international requirements 
concerning products and social issues. In addition, in developed countries, governments are the main promotors of corporate social responsibility practices, while in developing countries, governments are reluctant to legislation concerning the environment, labor conditions or curbing corruption. A similar opinion is shared by Jamali (2007), who noticed that corporate social responsibility does not raise particular interest in developing countries because the civil society in these countries is not sufficiently organized and governments do not promote corporate social responsibility practices.

On the other hand, Lähtinen and Myllyviita (2015) show in their study that topics such as "impact on landscape", "length of impact", "spiritual values", "persistence of traditions" and "adaptability to cultural changes" are not at all approached in GRI guides.

Certain studies (Konrad et al., 2006; Waddock, 2008; Perez-Batres, Miller and Pisan, 2010) suggest that the desire to gain the market's trust, to attract or maintain investors, respectively to improve a country's image, is relevant in the process of adopting GRI standards. Other authors (Khanna, 2001; Porter and Kramer, 2006) consider that adopting corporate social responsibility standards can be used to identify competitive advantages.

\section{Research methodology}

In order to estimate the degree of compliance with GRI in corporate reporting at international level, we started from the GRI database, the limited version (available at https://www.globalreporting.org/services/Analysis/Report s_List/Pages/default.aspx), which comprises GRI reports published over the last three years $(2013,2014,2015)$ and we analyzed the structure of these reports according to the following classification criteria: geographic distribution, sector of activity, category of enterprise and its relation to OECD. Within each category we then identified the degree of compliance with the various variants of GRI guides. Also, in order to study the evolution of tendencies to report according to GRI across a longer period of time, we included in the analysis the study performed in 2012 by Marimon, Alonso-Almeida şi Rodriguez which also started from the GRI database, and which covers the period 1999-2010.

The database that we used in our study comprises the following categories of information: data about the reporting organization (its name, size, sector, country, region) and data about reports (year of publication and type of report). For the year 2013, it also supplies information concerning the status of countries relative to the OECD. The number of entries in the database is significant: 4,828 firms for the year $2013,5,211$ firms for the year 2014 and 2,913 firms for the year 2015 . The low number of entries for the year 2015 can be explained by the fact that we collected the information at the beginnig of 2016 and the registration of reports on the previous year in the database is underway. Our study tackled only GRI certified reports (which comply with GRI, even though to different extents); hence, in comparison with the number of entries in the initial database, our study included 3,238 firms for the year 2013, 3,981 firms for the year 2014 and 2,405 firms for the year 2015. The analysis has been intuitive, based on direct observation and the comparative analysis of the database content, which allowed us to describe and explain the identified trends. For data processing, we started from the previously mentioned database, which is in an Excel format, and we used the facilities provided by Microsoft Office - Excel Pivot Tables. A limit of our study consists in the short period of time that we analyzed directly due to the lack of availability of data for previous time intervals.

\section{Reporting according to GRI along geographical areas and depending on the status of countries in relation to the OECD}

The highest number of GRI certified reports was registered in 2014: 3,981 companies published sustainability reports acording to GRI, at world level, while in 1999 there had been just 6 companies. Developments for each region are presented in Table 1. Europe and Asia have the highest number of GRI certified reports. There are a few explanations for this state of facts: the European Comission declared 2005 the year of corporate social responsibility for European Union countries; Great Britain was the first country which appointed a minister to supervise sustainability policies; in France, there is the legal obligation that firms with more than 300 employees should draw social responsibility reports (Marimon, Alonso-Almeida and Rodriguez, 2012). At the same time, Finland, Sweden and Spain started accepting and imposing corporate 
social responsibility rules at national level (Levy, Brown and de Jong, 2010). With reference to Asia, Welford showed in 2005 that although this area had registered a high rate of increase in the past years, however, its contribution to social resposibility was still minor. This lack of activity was accounted for by the legislation which establishes, imperatively, the number of working hours, the maximum number of extra hours and the structure of salary expenses. Also, the author referred to the fact that long hours are a habitual practice in Asia.

\section{Table 1. Geographic distribution of reporting according to GRI at world level}

\begin{tabular}{|r|r|r|r|r|r|r|r|}
\multicolumn{1}{r|}{ Year } & \multicolumn{1}{c|}{ Africa } & \multicolumn{1}{c|}{ Asia } & \multicolumn{1}{c|}{ Europe } & \multicolumn{1}{c|}{$\begin{array}{l}\text { Latin } \\
\text { America }\end{array}$} & \multicolumn{1}{c|}{$\begin{array}{l}\text { North } \\
\text { America }\end{array}$} & \multicolumn{1}{l|}{ Oceania } & \multicolumn{1}{l|}{ Total } \\
\hline 1999 & 0 & 1 & 0 & 0 & 5 & 0 & 6 \\
\hline 2000 & 3 & 7 & 1 & 1 & 2 & 1 & 15 \\
\hline 2001 & 1 & 1 & 15 & 2 & 6 & 9 & 34 \\
\hline 2002 & 8 & 3 & 22 & 9 & 31 & 12 & 85 \\
\hline 2003 & 2 & 3 & 54 & 5 & 31 & 10 & 105 \\
\hline 2004 & 22 & 8 & 115 & 9 & 47 & 14 & 215 \\
\hline 2005 & 23 & 29 & 180 & 17 & 50 & 23 & 322 \\
\hline 2006 & 25 & 39 & 223 & 51 & 70 & 40 & 448 \\
\hline 2007 & 24 & 85 & 342 & 80 & 27 & 48 & 606 \\
\hline 2008 & 51 & 185 & 457 & 141 & 38 & 71 & 943 \\
\hline 2009 & 54 & 304 & 647 & 189 & 83 & 90 & 1367 \\
\hline 2010 & 55 & 367 & 829 & 258 & 66 & 81 & 1656 \\
\hline 2013 & 167 & 1119 & 1344 & 613 & 439 & 122 & 3804 \\
\hline 2014 & 167 & 1183 & 1443 & 619 & 453 & 116 & 3981 \\
\hline 2015 & 47 & 702 & 940 & 418 & 274 & 24 & 2405 \\
\hline
\end{tabular}

Source: Marimon, Alonso-Almeida, and Rodríguez (2012) and GRI database (2016)

Figures 1 and 2 provide a synthetic representation of the evolution of reporting according to GRI. They capture the hightened increasing trend of this type of reporting until the year 2010, whereas in the period 2013-2014, the increasing trend was maintained, but at a moderate pace.

\section{Figure 1. Evolution of reporting according to GRI during the period 2001-2010}

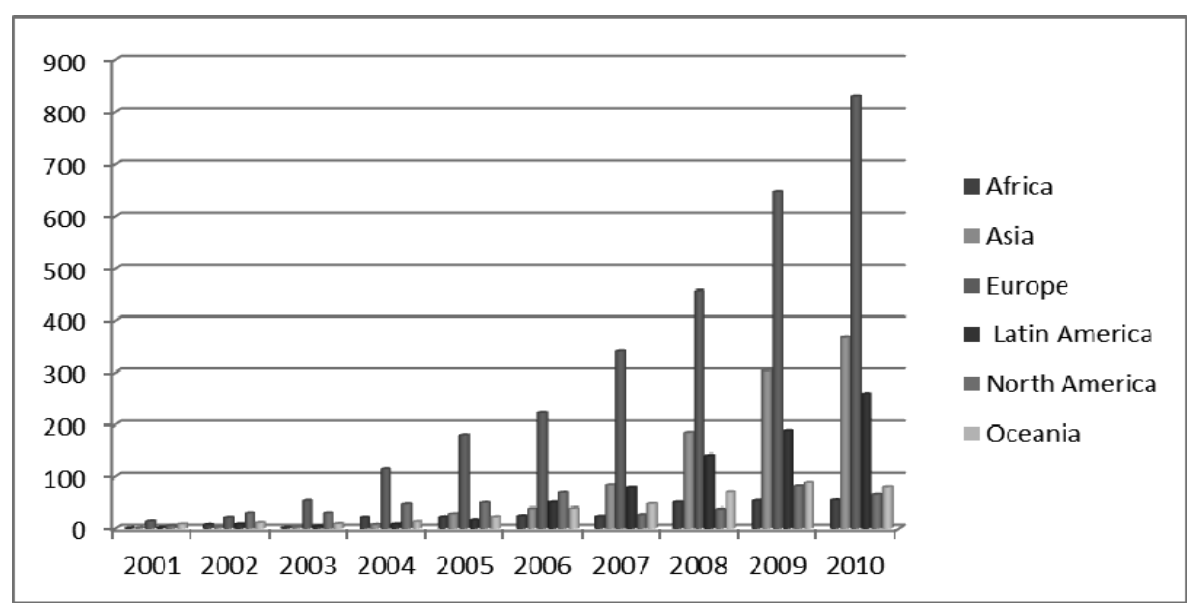

Source: Own processing. 


\section{Figure 2. Evolution of reporting according to GRI during the period 2013-2014}

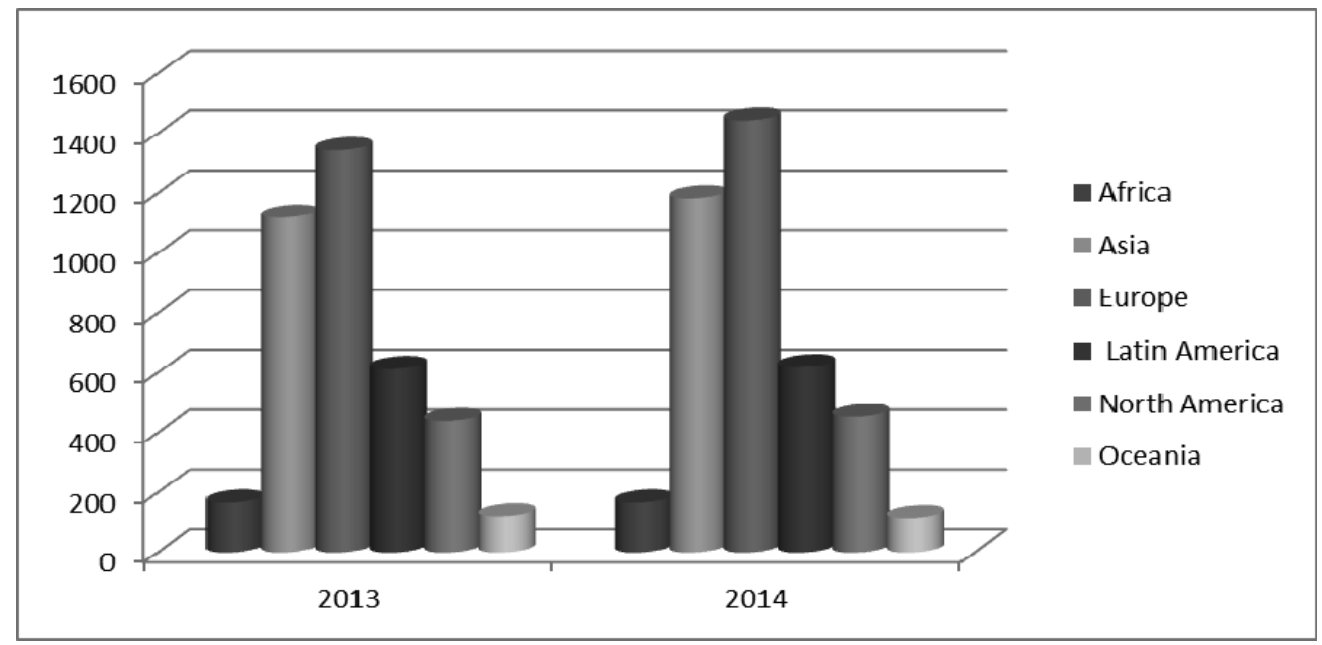

Source: Own processing

In our analysis, one element that can be surprising is the low level of reporting according to GRI (as well as the very low increase rate of reporting during the period 1999-2010), registered among countries from North America - an area in which we have been accustomed to think of the USA as a promoter of reports to all categories of stakeholders. One possible explanation could be that although USA grants special attention to activities covered in sustainability reports, it does not need the GRI guide because companies that supply information on social and sustainability policies use other channels. However, during the last time interval analyzed
(2013-2014), at the level of North America, a higher increase rate was registered, although the level of reporting fails to come even close to half of the level registered in Europe. It is possible that this rise is the result of the increasingly stronger perception that the latest financial crisis was caused especially by the financial service sector, which is strongly represented in the USA.

Depending on the status of the country in which the reporting company is located, relative to the OECD, we noticed that for the year 2013 (the only one for which the GRI database supplies data), the situation concerning reporting according to $\mathrm{GRI}$ is as follows:

\section{Table 2. Reporting according to GRI depending on country status relative to OECD}

\begin{tabular}{|l|r|r|r|r|r|r|}
\hline & GRI - G3 & \multicolumn{1}{|c|}{ GRI - G3.1 } & GRI - G4 & $\begin{array}{c}\text { GRI - } \\
\text { Referenced }\end{array}$ & Total & Pecentage \\
\hline Member of OECD & 771 & 1,054 & 45 & 335 & 2,205 & $57.97 \%$ \\
\hline $\begin{array}{l}\text { Receives development } \\
\text { aid through the OECD } \\
\text { Development Assistance } \\
\text { Committee (DAC) }\end{array}$ & 421 & & & & & \\
\hline Non-OECD / Non-DAC & 33 & 789 & 16 & 215 & 1,441 & $37.88 \%$ \\
\hline
\end{tabular}

Source: Own processing

We can notice that OECD member countries have the highest number of companies that report according to
GRI $-57.97 \%$, followed by countries which receive development aid through the OECD Development 
Assistance Committee (DAC) - 37.88\%, while the number of firms which report according to GRI in countries which are not OECD members or which do not benefit from OECD support is very low $-4.15 \%$.

\section{Reporting according to GRI along sectors of activity, according to the category of firms and types of reports}

The conducted analysis showed that reporting according to GRI was adopted by 38 different sectors of activity. Figure 3 indicates an increasing tendency to use GRI in each sector that is in top 9 in terms of reporting according to $\mathrm{GRI}$ (together, the analysed sectors represent $47 \%$ of GRI reports in each of the analyzed years).
The increasing tendency identified by us confirms the same evolution identified by Marimon, AlonsoAlmeida and Rodriguez (2012) in a study that concerned the period 1999-2010. Unlike the mentioned study, which pointed out a hightened increase in reporting according to GRI, especially after 2006 (when GRI - G3.1 was issued), our research highlights a moderate increasing tendency. Although GRI initially emerged especially as a reporting recommendation concerning aspects connected to the enviornment, we noticed, just like Marimon, Alonso-Almeida and Rodriguez (2012) that financial services are the best represented sector over the last years in reporting according to GRI. Ogrizek (2002) suggests that this increasing tendency is the result of the influence of USA, where legal factors and activism establish the lines of action of companies that offer financial services.

\section{Figure 3. Distribution of GRI reports along sector of activity (sectors in top 9 in the 2016 GRI database)}

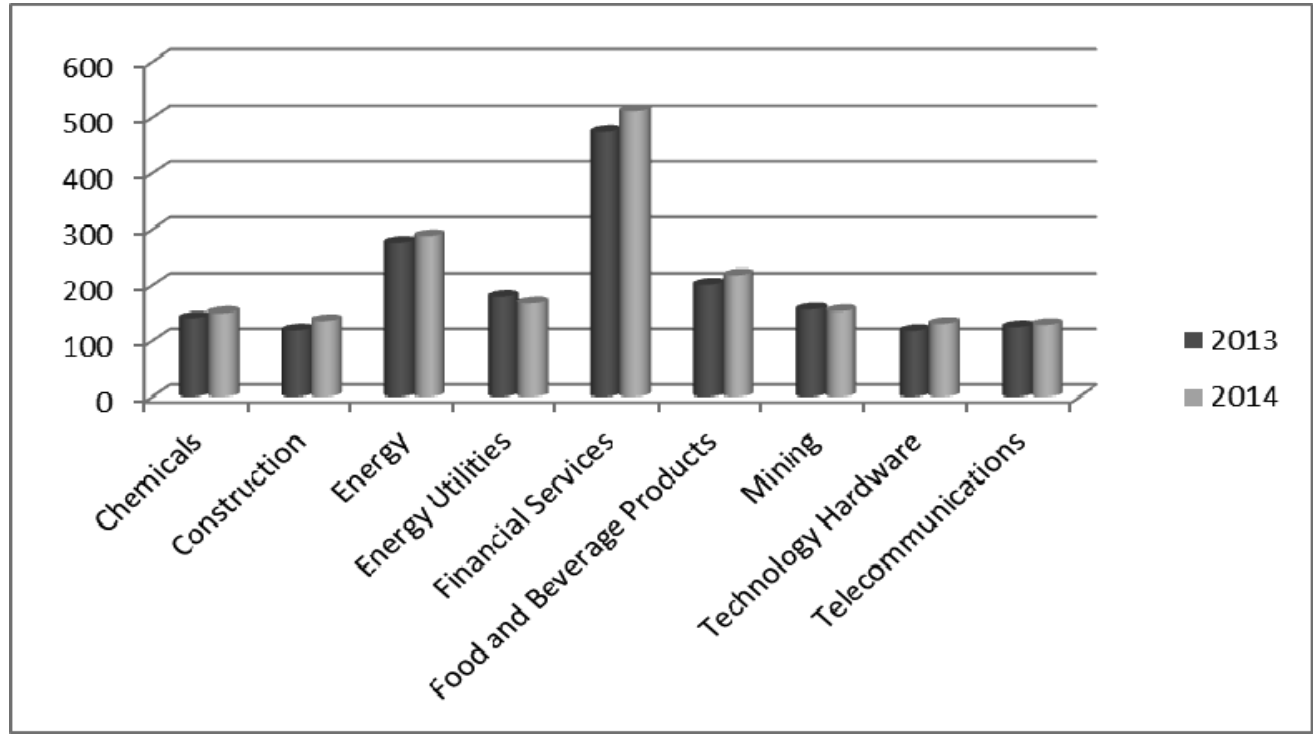

Source: own processing

We noticed that the energy sector (including the oil industry), the chemicals and mining are in the category of top sectors as far as reporting according to GRI is concerned, probably due to the (real or potential) negative influence of these sectors on the environment. Also, we noticed that companies operating in constructions, food and beverage products, technology hardware and telecommunications industries are proactive in publishing corporate social responsibility reports, thus showing a hightened sensitivity to social and environmental problems.

By analyzing the structure of reporting according to GRI relative to company size and its evolution during the time interval covered by our study, we noticed that the top 
position is occupied by large companies (which, by the EU definition, have more than 250 employees and a turnover higher than 40 million Euro or a total of the balance sheet higher than 20 million Euro - EU, 2013), seconded by multinationals, followed, in the third position, by small and medium size companies. Similar results had previously been obtained by Preuss and Barkemeyer (2011).

\section{Figure 4. Distribution of GRI reports according to category offirms}

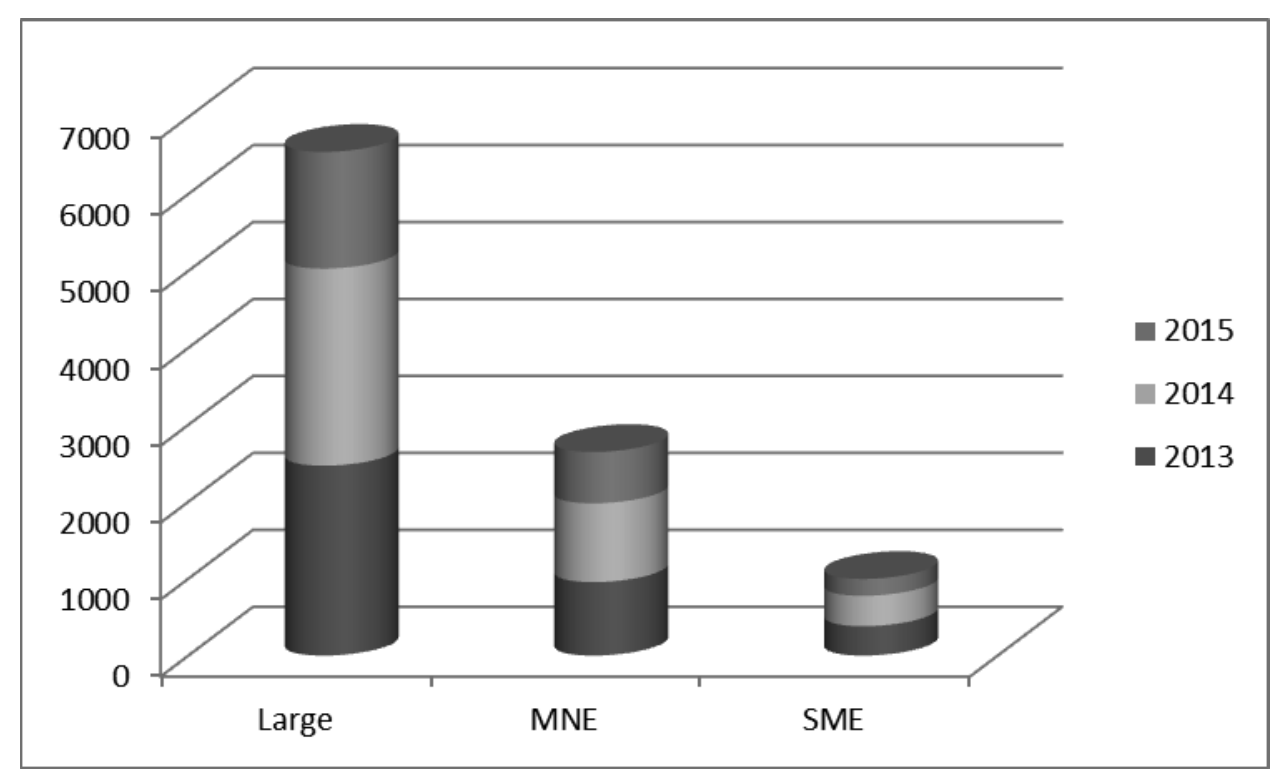

Source: Own processing

The result was predictable given that the process to collect, check and elaborate these reports supposes very high costs.
A final structure analysis aimed to estimate compliance of reports with the GRI guides that are currently applicable (GRI - G3, GRI - G3.1 and GRI - G4).

\section{Figure 5. Comparative situation of the evolution of reports according to their compliance with GRI guides}

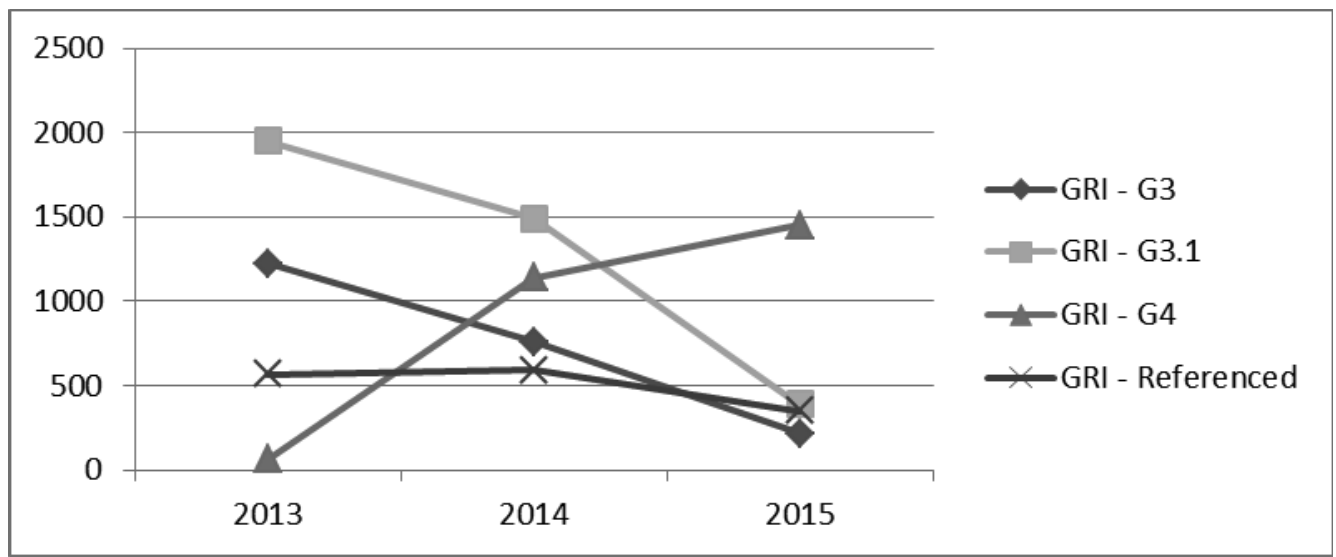

Source: Own processing

No. 4(136)/2016 
Whereas before the emergence of GRI - G4, one could notice a relatively constant increase of reports prepared according to GRI - G3 and GRI - G3.1, after the publication of GRI - G4 in 2013, the number of reports prepared according to third generation guides dropped, while the number of reports prepared according to GRI G4 increased. The evolution is not surprising if we consider that the writing up of new guides is carried out after a constant and structured process of consulting stakeholders, among which are especially firms interested in the process of reporting according to GRI. Therefore, any new guide meets company reporting intentions first of all, and subsequently, the information requirements of stakeholders. This context can also explain the relatively constant number of reports that take GRI as a reporting model, without complying with any particular guide.

\section{Discussion and conclusion}

First, we noticed that companies which operate in Europe and in Asia are ranked on the top position as far as publication of reports written according to GRI is concerned, and they are followed by companies that operate in Latin America.

Our observations confirm certain previous results. Thus, Waddock (2008) identifies the highest rate of GRI adoption in China and explains it by the fact that this country has been accused of disasters and abuse in terms of free competion and human rights; hence, China is concerned with improving its corporate social reporting practices and its reputation in terms of sustainability.

Second, a significant percentage of companies which operate in OECD member countries or in countries that benefit from assistance from the Committee to support OECD development report according to GRI, while companies situated in countries that are not OECD members or that do not benefit from this organization's support report according to GRI in an insignificant percentage.

Third, we noticed that GRI guides are adopted by companies which operate in sectors of high environmental risk (the chemicals, mining and energy). Many of these firms are also very visible on the capital market.
Fourth, we noticed a relatively constant increasing tendency among firms that report according to GRI, with a focus on large enterprises and multinational companies, that have significant resources. As Levy, Brown and de Jong (2010) also show, GRI standards and guides are ignored by small and medium size enterprises because publishing non-financial information is costly and quite complex.

Finally, we identified the firms' tendency to comply with the most recent guides and recommendations for corporate reporting, under the circumstances where several variants are applicable. Therefore, with the emergence of $\mathrm{G} 4$, one can notice an increase in reporting according to this guide, paralleled by the decrease in the number of companies that report according to G3. The phenomenon is logical and it was noticed also in the transit stage from $\mathrm{G} 3$ to $\mathrm{G} 3.1$.

Unlike previous studies that were carried out on a much smaller number of companies (for instance, Marimon, Alonso-Almeida and Rodriguez carried out a study on the GRI database from 2010 , which comprised only 1,656 companies), our research used the GRI database from 2016, which comprises a significant number of registrations (the highest number of analyed companies was 5,211, in 2014). The limit was given by the smaller number of years for which we have managed to perform our analysis. However, the results obtained by us agreed with those obtained in previous studies.

Given what we have noticed so far, one can anticipate an increase in the degree of adopting GRI practices, despite the high costs associated to data collection, to report writing and checking (Koerber, 2010). Moreover, certain authors (Brown, de Jong and Lessidrenska, 2009) consider that the process to develop GRI standards will continue and it will benefit from support as long as new guides will be issued, with specific information for certain sectors and countries.

KPMG's latest study (2015) on corporate responsibility reporting shows that the tendency among companies to include more information on corporate responsibility in their annual financial reports is determined by two factors: first, information concerning corporate responsibility is increasingly 
more perceived by shareholders as relevant to understand risks and opportunities that are specific to the company and, second, stock exchanges and governments institute requirements for companies concerning the inclusion of corporate responsibility data in annual reports.

Yet, the Volskwagen scandal raises many questionmarks concerning what can be hidden in the very detailed and bulky reports that comply with the highest corporate social responsibility standards. Thus, an article by Schwindenhammer (2013) shows that 5 German companies (BASF, Bayer, Daimler, RWE and Volkswagen) fully comply with GRI norms and, in addition, this observance is externally assured by suppliers of auditing services. The study also makes reference to an analysis performed in 2010 by the Institute for Ecological Economy Research, which indicates that firms which comply with GRI are best ranked in the hierarchy of firms that report sustainability information appropriately. However, despite this information supplied by German researchers, the Volkswagen scandal shows that, beyond reports that wish to present a certain image of the company, reality can be much different and, what is more serious, even in contradiction to these reports.

\section{REFERENCES}

1. Brown, H.S., de Jong, M. and Lessidrenska, T. (2009), The rise of the Global Reporting Initiative (GRI): a case of institutional entrepreneurship, Environmental Politics, vol. 18, no. 2, pp. 182-200, DOI: http://dx.doi.org/10.1080/ 09644010802682551.

2. Chersan, I.-C. (2015), Study on Practices and Tendencies in Integrated Reporting, Audit Financiar, vol. 13, no. 9(129), pp. 91-101.

3. Clarkson, P.M., Overell, M.B. and Chapple, L. (2011), Environmental Reporting and its Relation to Corporate Environmental Performance, Abacus, vol. 47, no. 1, pp. 27-60, DOl: http://dx.doi.org/ 10.1111/j.1467-6281.2011.00330.x.

4. Elkington, J. (1994), Towards the sustainable corporation: Win-win-win business strategies for sustainable development, California Management Review, vol. 36, no. 2, pp. 90-100.

5. EU (European Union) (2013). Directive 2013/34/EU of the European Parliament and of the Council of 26 June 2013 on the annual financial statements, consolidated financial statements and related reports of certain types of undertakings, amending Directive 2006/43/EC of the European Parliament and of the Council and repealing Council Directives 78/660/EEC and 83/349/EEC. Retrieved from http://eur-lex.europa.eu/legal-content/EN/TXT/PDF/ ?uri=CELEX:32013L0034\&from=EN.
6. European Commission (2011). A renewed EU strategy 2011-14 for corporate social responsibility. COM(2011) 681. Brussels: European Commission, [pdf] Available at: http://eur-lex.europa.eu/LexUri Serv/LexUriServ.do?uri=COM:2011:0681:FIN:en:P DF [Accessed 7 February 2016].

7. Global Reporting Initiative (2000), Sustainability Reporting Guidelines, Version 3.0, [pdf] Available at: https://www.globalreporting.org/ resourcelibrary/G3-Guidelines-Incl-TechnicalProtocol.pdf, [Accessed 7 February 2016].

8. Global Reporting Initiative (2000), Sustainability Reporting Guidelines, Version 3.1, [pdf] Available at: https://www.globalreporting.org/ resourcelibrary/G3.1-Guidelines-Incl-TechnicalProtocol.pdf, [Accessed 7 February 2016].

9. Global Reporting Initiative (2000), G4 Sustainability Reporting Guidelines. Reporting Principles and Standard Disclosures, [pdf] Available at: https://www.globalreporting.org/resourcelibrary/GRI G4-Part1-Reporting-Principles-and-StandardDisclosures.pdf, [Accessed 7 February 2016].

10. Global Reporting Initiative (2016), GRI Reports List (Limited Version) - 01.03.2016, [online] Available at: https://www.globalreporting.org/ services/Analysis/Reports_List/Pages/default.aspx, [Accessed 7 February 2016]. 
11. Jamali, D. (2007), The Case for Strategic Corporate Social Responsibility in Developing Countries, Business and Society Review, vol. 112, no. 1, pp. 1-27, DOI: http://dx.doi.org/10.1111/ j. 1467-8594.2007.00284.x.

12. Khanna, M. (2001), Non-mandatory approaches to environmental protection, Journal of Economic Surveys, vol. 15, no. 3, pp. 291-324, DOI: http://dx.doi.org/10.1111/1467-6419.00141.

13. Koerber, C.P. (2010), Corporate responsibility standards: current implications and future possibilities for peace through commerce, Journal of Business Ethics, vol. 89, nr. 4 (suplim.), pp. 461-480.

14. Konrad, A., Steurer, R., Langer, M.E. and Martinuzzi, A. (2006), Empirical findings on business-society relations in Europe, Journal of Business Ethics, vol. 63, no. 1, pp. 89-105, DOl: http://dx.doi.org/10.1007/s10551-005-7055-z.

15. KPMG (2015), Currents of change: The KPMG Survey of Corporate Responsibility Reporting 2015, [pdf] Available at: https://www.kpmg.com/CN/en/lssuesAndlnsights/A rticlesPublications/Documents/kpmg-survey-ofcorporate-responsibility-reporting-2015-O201511.pdf, [Accessed 6 February 2016].

16. Lähtinen, K. and Myllyviita, T. (2015), Cultural sustainability in reference to the global reporting initiative (GRI) guidelines: Case forest bioenergy production in North Karelia, Finland, Journal of Cultural Heritage Management and Sustainable Development, vol. 5, no. 3, pp. 290-318, DOI: http://dx.doi.org/10.1108/jchmsd-06-2013-0025.

17. Levy, D., Brown, H.S. and de Jong, M. (2010) The Contested Politics of Corporate Governance: The Case of the Global Reporting Initiative, Business \& Society, vol. 49, no. 1, pp. 88-115, DOl: http://dx.doi.org/10.1177/0007650309345420.

18. Ligteringen, E. and Zadek, S. (2005), The Future of Corporate Responsibility Standards, Business and the Environment, vol. 16, no. 6, pp. 12-13.

19. Marimon, F., Alonso-Almeida, M. del M. and Rodríguez, M del P. (2012), The Worldwide diffusion of the Global Reporting Initiative: what is the point?, Journal of Cleaner Production, vol. 33, pp. 132-144, DOI: http://dx.doi.org/10.1016/ j.jclepro.2012.04.017.

20. Ogrizek, M. (2002), The effect of corporate social responsibility on the branding of financial services, Journal of Financial Services Marketing, vol. 6, no. 3, pp. 215-228, DOI: http://dx.doi.org/10.1057/ palgrave.fsm. 4770053 .

21. Perez-Batres, L.A., Miller, V.V. and Pisan, J.P. (2010), CSR, sustainability and the meaning of global reporting for Latin American corporations, Journal of Business Ethics, vol. 91, no. 2 (supplem.), pp. 193-209.

22. Porter, M.E. and Kramer, M.R. (2006), Strategy \& society: the link between competitive advantage and corporate social responsibility, Harvard Business Review, vol. 84, no. 12, pp. 78-92.

23. Prado-Lorenzo, J.-M., Gallego-Alvarez, I. and Garcia-Sanchez, I.M. (2009), Stakeholder engagement and corporate social responsibility reporting: the ownership structure effect, Corporate Social - Responsibility and Environmental Management, vol. 16, no. 2, pp. 94-107, DOI: http://dx.doi.org/10.1002/csr.189.

24. Preuss, L. and Barkemeyer, R., (2011) CSR priorities of emerging economy firms: is Russia a different shape of BRIC?, Corporate Governance: The International Journal of Business in Society, vol. 11, no. 4, pp. $371-385$.

25. Risse, T. (2007), Social constructivism meets globalization. In D. Held \& A. McGrew (Eds.), Globalization theory. Approaches and controversies, pp. 126-147, Cambridge, Polity Press.

26. Skouloudis, A., Evangelinos, K. and Kourmousis, F. (2009), Development of an Evaluation Methodology for Triple Bottom Line Reports Using International Standards on Reporting, Environmental Management, vol. 44, no. 2, pp. 298-311, DOI: http://dx.doi.org/10.1007/s00267009-9305-9.

27. Schwindenhammer, S. (2013), Patterns and Explanations of Corporate Voluntary Norm Compliance: Results from a Structured Focused Comparison of German G500 in the Global Reporting Initiative, German Policies Studies, vol. 9, no. 2, pp. 123-160. 
28. Waddock, S. (2008), Building a new institutional infrastructure for corporate responsibility, Academy of Management Perspectives, vol. 22, no. 3, pp. 87 - 108, DOI: http://dx.doi.org/10.5465/AMP. 2008.34587997.
29. Welford, R. (2005), Corporate Social Responsibility in Europe, North America and Asia. 2004 Survey Results, The Journal of Corporate Citizenship, vol. 17, pp. 33-52, DOI: http://dx.doi.org/10.9774/ gleaf.4700.2005.sp.00007. 